\title{
Florida Edible Garden Plants: Hops (Humulus lupulus) ${ }^{1}$
}

\author{
Brian J. Pearson ${ }^{2}$
}

\section{Introduction}

Hops (Humulus lupulus) are perennial, herbaceous climbing plants commonly cultivated for their strobiles or cones (Figure 1). The cones are often used for flavoring and aroma in food, tea, and beer (Burgess 1964). Hops can make a unique addition to a home garden or landscape. It grows

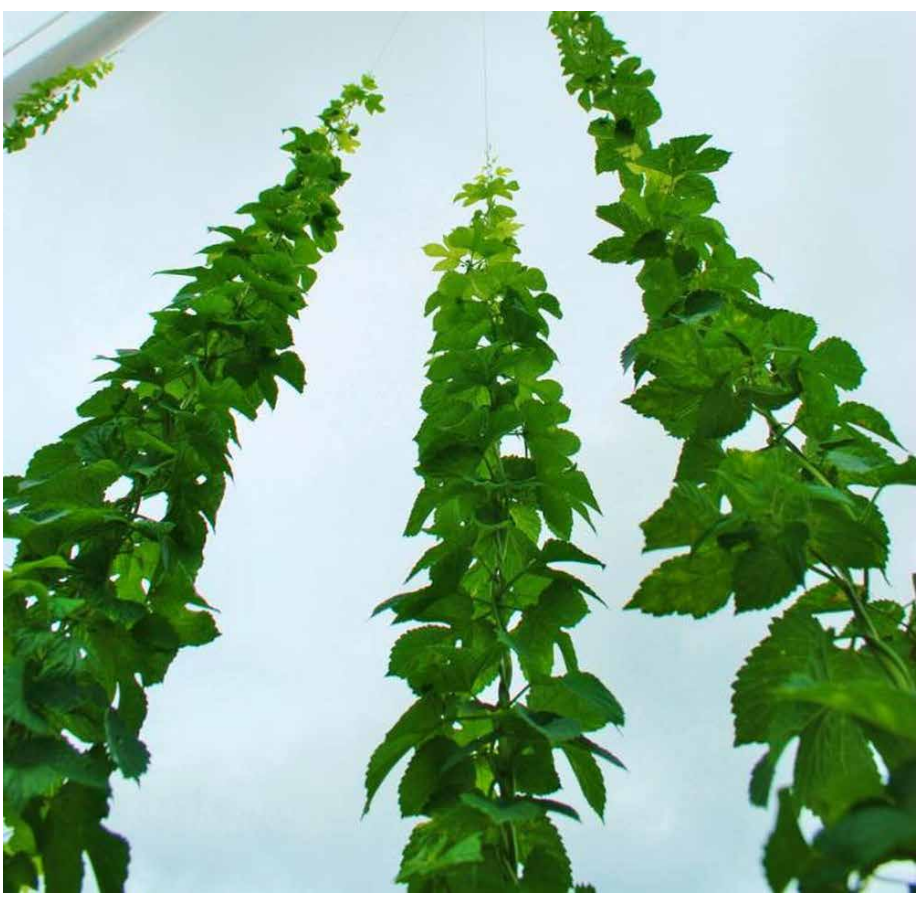

Figure 1. These hops grown in Central Florida were planted on April 18,2013 , and the picture was taken 3.5 months after planting on July 26. The plants are approximately 16 feet high, growing up a twine support. Credits: Brian J. Pearson rapidly in the early spring to late summer. Plants reach a mature height of 18-25 feet in one year and produce cones from mid-summer to early fall.

Common name: Hops

Scientific name: Humulus lupulus

Plant family: Cannabaceae

\section{Outdoor Cultivation Information} USDA Hardiness Zone: Hops prefer USDA Hardiness Zones 4 to 8 (for more information on USDA Hardiness Zones, see http://planthardiness.ars.usda.gov/PHZMWeb/). Preliminary tests show hops can tolerate zones outside of this range (Zone $9 \mathrm{~b}$ ).

Soil preference: Hops grow best in well-drained, humus-rich soil with a $\mathrm{pH}$ of 6.0-6.5. Soil preparation is important for optimal plant growth. Organic matter, such as composted manure, biosolids, and yard waste, can be amended into the top 4-8 inches of soil using a rototiller, shovel, or spading fork to improve soil characteristics for plant growth.

Light requirement: Hops require full sun for maximum cone production.

1. This document is ENH1227, one of a series of the Environmental Horticulture Department, UF/IFAS Extension. Original publication date: October 2013. Please visit the EDIS website at http://edis.ifas.ufl.edu.

2. Brian J. Pearson, assistant in-teaching, Environmental Horticulture Department, Mid-Florida Research and Education Center, UF/IFAS Extension, Apopka, FL 32703.

The use of trade names in this publication is solely for the purpose of providing specific information. UF/IFAS does not guarantee or warranty the products named, and references to them in this publication do not signify our approval to the exclusion of other products of suitable composition. 
Water requirement: Irrigate hops regularly, but provide drainage.

Drought tolerant: Yes. Hops have the ability to tolerate drought.

Fertilizer requirements: Apply a well-balanced, slowrelease pelletized (granular or encapsulated) fertilizer such as Osmocote ${ }^{\circledR}$ or Nutricote ${ }^{\circledR}$ according to manufacturer recommendations during the spring and summer.

Temperature preference: Although hops prefer a mean annual temperature of $42^{\circ} \mathrm{F}-70^{\circ} \mathrm{F}$, they can survive in Florida summers.

Freeze tolerant (below $32^{\circ}$ F): No. Hops defoliate in late fall as the plant enters winter dormancy. Plant material should be pruned after defoliation occurs. New shoots will emerge when the plant breaks dormancy in early spring.

Pests/Disease: The following can affect production of hops: mites (Tetranychus urticae), downy mildew (Pseudoperonospora humuli), and powdery mildew (Sphaerotheca humuli) (Mahaffee and Pethybridge 2009). Take a sample to your local UF/IFAS Extension agent to confirm identification and receive treatment instructions; to find your local UF/ IFAS Extension office, visit http://solutionsforyourlife.ufl. edu/map/.

Origin: Asia, Europe, and North America

Availability: Humulus lupulus rhizomes can be purchased from online and mail order vendors from mid-March through May. Rhizomes should be purchased as early as possible for March/April planting in Florida before temperatures become high. Rhizomes should be placed horizontally or vertically in the soil approximately 1 inch below the surface. Shoots from newly planted rhizomes will emerge within 2-3 weeks after planting.

Notes: Humulus lupulus can be trained on a trellis or twine strung on poles, bars, or fences. Plant growth slows after summer solstice (June 21), and small flowers (Figure 2) begin to emerge from each node approximately 3-4 feet from the soil surface. As flowers mature, they develop into cones (Figure 3 ) and ripen mid-summer to early fall, depending on the variety. Cones are ripe and optimal for harvest when dry and papery to the touch. If the cones are not used directly after harvest, they should be air dried, stored in an air-tight container, and placed in a freezer until use.

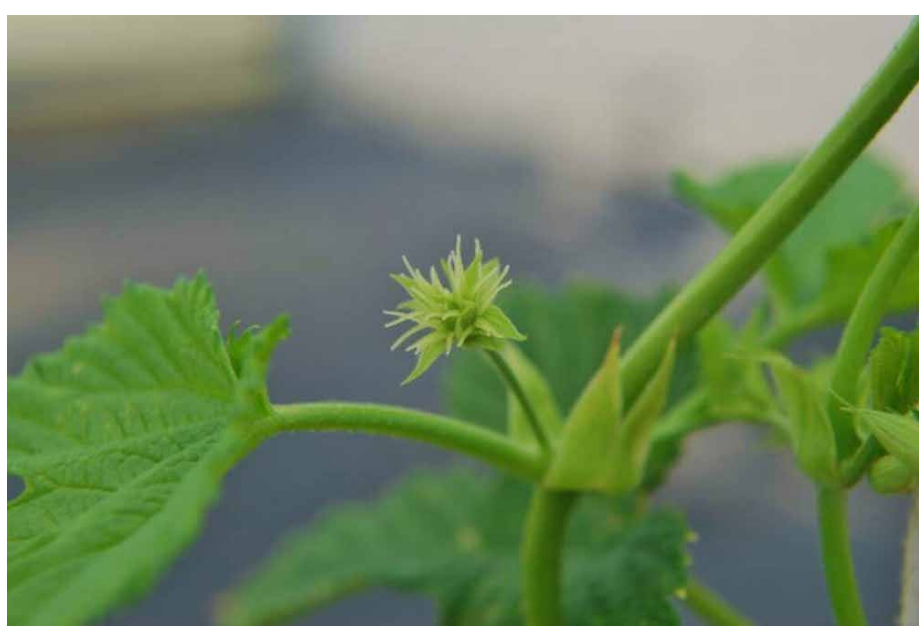

Figure 2. This hop (Humulus lupulus) female flower will develop into a harvestable cone. Credits: Brian J. Pearson

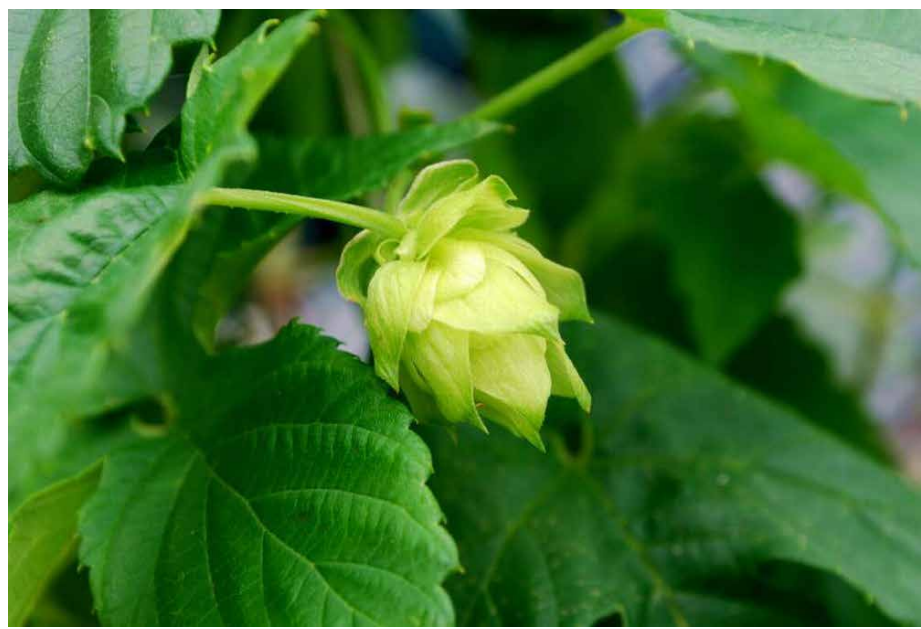

Figure 3. This hop (Humulus lupulus) strobile (cone) will develop from the flower and is almost ready for harvest. This photo was taken on August 5, 2013 in Apopka, FL. Credits: Brian J. Pearson

\section{References}

Burgess, A. 1964. Hops: Botany, Cultivation, and Utilization. New York: Interscience Publishers.

Mahaffee, W., and S. Pethybridge. 2009. "The Genus Humulus." In Compendium of Hop Diseases and Pests, edited by W. F. Mahaffee, S. Pethybridge, and D. H. Gent, 1-5. St. Paul, MN: The American Phytopathological Society. 